\title{
Ethnomedicinal studies of some tree species of Chamba district (Himachal Pradesh) India.
}

Asha Arora $^{1 *}$, Mukesh Sharma ${ }^{2}$ and Sushma Gupta ${ }^{3}$

${ }^{1}$ Department of Biotechnology, B N University, Udaipur (Raj.), India

${ }^{2}$ Department of Botany, Pacific College Udaipur (Raj.)India

3SDAM College, Dina Nagar, Gurdaspur (Punjab) India.

Received: 1/14/2018; Accepted: 1/19/2018

\begin{abstract}
The present study encompasses 121 ethno-medicinal uses of 26 tree species of 20 families deployed for 75 maladies and 16 body systems as included in WHO-ICD 11 by Gaddi and Gurjar tribes of Chamba region (Himachal Pradesh). Tribal's were more familiar to therapeutic plants used for digestive disorders i.e. 24 use reports of 16 tree species followed by skin maladies and localized infections. No citation regarding immune system, circulatory, sensory systems, mental, behavioral / neuro-developmental disorders, sleep-wake disorders, conditions related to sexual health and injury, poisoning or certain other consequences of external causes was obtained. Taxus baccata was found to be most versatile species of the region as it was deployed in 13 diseases of 8 body systems.
\end{abstract}

Keywords: Gaddi, Gurjar, Chamba, ICD 11, Taxus baccata

\section{Introduction}

Himachal Pradesh has been regarded as a veritable emporium of plant genetic resources housing huge diversified medicinal and aromatic plants. It is a rich repository of medicinal wealth and occupies an important place in the Vedic treatises. In ancient times, it has been the abode of saints and sages, who pursued meditational and scholarly endeavors. According to Ayurvedic Pharmacopoeia Committee, Government of India, out of 1100 single ingredient drugs, 350 plants belong to indigenous therapeutic group among which 225 species bloom in Himachal Pradesh and are utilized for commercial extraction. However, no proper records are available for such transactions (Chauhan, 2003). There is an urgent need to identify pertaining natural wealth and make people aware to know their utilities and its repercussions before they are extinct. The exploration is utmost important or this valuable and unbeatable information will be lost forever (Singh and Minoo, 2003).

According to the Census 2011, 5.71\% of the state population belongs to Scheduled Tribes. The major tribes include - Bhot, Bodh, Gaddi, Gujjar, Jad, Lamba, Khampa, Kanaura, Kinnara, Lahaula, Pangwala, Swangla, Demba, Gara, Beta, Beda and Zoba. The highest tribal population resides in Chamba followed by Kangra and Kinnaur. These tribes are believed to be the descendent of IndoAryan lineages. Chamba district is also considered as one of the richest areas of traditional and potential medicinal wealth. It has 10 tehsils viz. Bhalai, Bhattiyat, Brahmaur, Chamba, Chaurah, Dalhousie, Holi, Pangi, Saluni and Sihunta and inhabits 1110 villages. Tribal's rich Pangi tehsil falls in between north latitude $32^{\circ}-33^{\prime}$ and $33^{\circ}-19^{\prime}$ and between east longitude $76^{\circ}-15^{\prime}$ and $77^{\circ}-21^{\prime}$ and the Bharmour tehsil is situated approximately between the north latitude $32^{\circ}-11^{\prime}$ and $32^{\circ}-41^{\prime}$ and in between the east longitude $76^{\circ}-22^{\prime}$ and $76^{\circ}-53^{\prime}$. Snow glaciers, high altitudes and highly-rugged terrain, fed by fast flowing rivers and their tributaries are the peculiar features of these tribal areas.

The earlier documented medicinal lore of Chamba includes that of Gupta (1964 and 1971); Shabnam (1964); Thakur (2007); Guleria and Vasishth, (2009); Rani et al. (2013); Dutt et al.(2014) and Thakur et al.(2016) while Singh and Sharma (2006) gave a detailed account of floristic wealth of Chamba. Despite of countable documentation of medicinal folk lore no special account of tree species has been enumerated yet. Rouged mountains inhabit woody flora utmost as they prevail throughout years whereas herbs account for a very short season. Traditional therapeutic proceedings rely on nearby vicinity resources and tribal's least count on storage of drugs or its parts, so in hilly tracts of Chamba the tree species play more important role as compared to other plant habits. Therefore, it's essential to indentify and conserve species of pivotal importance.

According to WHO the application efficacy of traditional formulation can be recognized on two arrays i.e. its application for an ailment and its application for body systems. Hence in present study the documentation and its analysis were carried out using ICD 11 (WHO, 2017) for both the

\footnotetext{
*Corresponding Author:

Dr. Asha Arora,

Head, Department of Biotechnology,

B N University, Udaipur (Raj.), India.

E-mail: araudr@gmail.com
}

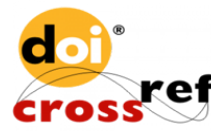


arrays i.e. usage for maladies and body system so that both versatile and a disease specific species can be identified.

\section{Materials and Methods}

For the documentation of medicinal uses of tree species, field surveys were carried out all around the year from 2014 to 2017 in various tribal, rural and sub-rural pockets i.e. Banikhat, Bhalai, Brangal, Brahmaur, Chamba, Chaurah, Chuari Khas, Dalhousie, Harsear, Holi, Saluni, Sinhunta, Tissa etc. of Chamba region of Himachal Pradesh.

For recording and documentation, field interviews were made from different practitioner's i.e. ritual therapist, herbalist, grain diviner, priest and ancestral practitioner through local transcends to avoid language ambiguity and data was recorded in information retrieval form. According to CBD guidelines prior informant consent (PIC) was

obtained and inscribed for usage, dose, mode of dose, tenure/ time interval etc.

Usage reports were categorized for both body systems and disease categories to evaluate the versatility and uniqueness of the reported plant. In case of poly-herbal preparation ratio of respective $\mathrm{drug} / \mathrm{s}$ and mode of usage was specifically noted. As some of the herbs prevents usage of other food/s and supplements/s as they directly or passively interacts with others, in such cases special notes were made for check modes.

In order to determine the authenticity of information collected during field visit, data was cross checked with published data of the same array and region. Data was also authenticated in criss cross manner by interviewing other informants.

\section{Observation}

Table 1.1: Ethno-medicinal enumeration of trees species used by tribal communities of Chamba district (Himachal Pradesh) to treat human diseases and disorders

\begin{tabular}{|c|c|c|c|c|c|c|}
\hline S.No. & $\begin{array}{l}\text { Botanical name } \\
\text { (Family) Local name }\end{array}$ & $\begin{array}{l}\text { Plant } \\
\text { part/s } \\
\text { used }\end{array}$ & $\begin{array}{l}\text { Form of } \\
\text { usage; } \\
\text { Application } \\
\end{array}$ & $\begin{array}{l}\text { Usage time } \\
\text { / Tenure }\end{array}$ & $\begin{array}{l}\text { Usage } \\
\text { amount }\end{array}$ & $\begin{array}{l}\text { Ailment/Disorder/Used as } \\
\text { (Disease category - ICD 11) }\end{array}$ \\
\hline 1. & $\begin{array}{l}\text { Albizia lebbeck (L.) } \\
\text { Benth. } \\
\text { (Fabaceae) Fuli }\end{array}$ & Seeds & Oil; Smear & $\begin{array}{l}\text { Film over } \\
\text { incision }\end{array}$ & - & Wound (14) \\
\hline \multirow{5}{*}{2.} & \multirow{5}{*}{$\begin{array}{l}\text { Baubinia variegata L. } \\
\text { (Caesalpiniaceae) Karale }\end{array}$} & \multirow[b]{2}{*}{ Roots } & $\begin{array}{l}\text { Decoction; } \\
\text { Orally }\end{array}$ & $\begin{array}{l}\text { Twice or } \\
\text { thrice as } \\
\text { prescribed }\end{array}$ & One cup & Snake bite(22) \\
\hline & & & \begin{tabular}{l}
\multicolumn{2}{c}{ Decoction } \\
with cider \\
vinegar $\quad(4: 1)$; \\
Orally
\end{tabular} & $\begin{array}{l}\text { Early } \\
\text { morning, } \\
\text { empty } \\
\text { stomach }\end{array}$ & One cup & $\begin{array}{l}\text { Obesity (05) and } \\
\text { As Carminative (13) }\end{array}$ \\
\hline & & Bark & $\begin{array}{l}\text { Paste; } \\
\text { Topically }\end{array}$ & - & - & $\begin{array}{l}\text { Skin rashes (14)and } \\
\text { Leprosy(01) }\end{array}$ \\
\hline & & $\begin{array}{l}\text { Floral } \\
\text { Buds }\end{array}$ & $\begin{array}{l}\text { Powder; } \\
\text { Orally }\end{array}$ & $\begin{array}{l}\text { Twice with } \\
\text { luke warm } \\
\text { water }\end{array}$ & $\begin{array}{l}\text { One } \\
\text { teaspoon }\end{array}$ & Dysentery(01) and Piles(13) \\
\hline & & $\begin{array}{l}\text { Flowers } \\
\& \text { Pods }\end{array}$ & Vegetable & - & - & As Anthelminthic (23) \\
\hline \multirow[t]{3}{*}{3.} & \multirow[t]{2}{*}{$\begin{array}{l}\text { Celtis australis } \mathrm{L} \text {. } \\
\text { (Cannabaceae) Khidak }\end{array}$} & \multirow[t]{2}{*}{ Roots } & $\begin{array}{l}\text { Paste; } \\
\text { Topically }\end{array}$ & - & - & Wounds(14) \\
\hline & & & $\begin{array}{l}\text { Decoction } \\
\text { with turmeric; } \\
\text { Orally as tea }\end{array}$ & $\begin{array}{l}\text { After } \\
\text { supper, } \\
\text { before bed }\end{array}$ & One cup & $\begin{array}{ll}\text { Cold and Cough (12) } \\
\text { Asthma(12) } & \\
\text { Bronchitis(12) } & \end{array}$ \\
\hline & Cinnamomum tamala & \multirow{3}{*}{ Leaves } & $\begin{array}{l}\text { Powder; } \\
\text { Orally }\end{array}$ & $\begin{array}{l}\text { Daily empty } \\
\text { stomach }\end{array}$ & One glass & Tuberculosis(01) \\
\hline \multirow{2}{*}{4.} & $\begin{array}{l}\text { Nees \& Eberm. } \\
\text { (Lauraceae) Tejpata }\end{array}$ & & $\begin{array}{l}\text { Infusion; } \\
\text { Orally }\end{array}$ & $\begin{array}{l}\text { With lemon } \\
\text { before meals }\end{array}$ & One cup & Carminative(13) \\
\hline & & & $\begin{array}{l}\text { Powder; with } \\
\text { boiled rice } \\
\text { filtrate }\end{array}$ & $\begin{array}{l}\text { During } \\
\text { menstrual } \\
\text { days }\end{array}$ & One cup & $\begin{array}{l}\text { Menstrual } \\
\text { Cramps(16) }\end{array}$ \\
\hline 5. & $\begin{array}{lll}\text { Citrus } & \text { limon } & \text { L. } \\
\text { (Rutaceae) } & \text { Nimbu }\end{array}$ & $\begin{array}{l}\text { Unripe } \\
\text { Fruits }\end{array}$ & $\begin{array}{l}\text { Roasted peel } \\
\text { powder; } \\
\text { Orally }\end{array}$ & $\begin{array}{l}\text { Twice a day } \\
\text { with like } \\
\text { warm water }\end{array}$ & $\begin{array}{l}\text { One tea } \\
\text { spoon }\end{array}$ & Liver complaints(13) \\
\hline 6. & $\begin{array}{lr}\text { Eucalyptus } & \text { citriodora } \\
\text { Hook. } & \text { (Myrtaceae) } \\
\text { Safeda } & \end{array}$ & Leaves & $\begin{array}{l}\text { Decoction; } \\
\text { Orally }\end{array}$ & - & - & $\begin{array}{l}\text { To wash wounds (14) and } \\
\text { Sores(01) }\end{array}$ \\
\hline 7. & $\begin{array}{l}\text { Eucalyptus bybridium L. } \\
\text { (Myrtaceae) Safeda }\end{array}$ & $\begin{array}{l}\text { Stem \& } \\
\text { Leaves }\end{array}$ & Juice; Poultice & - & - & Febrifuge(21) \\
\hline \multirow{3}{*}{8.} & \multirow{3}{*}{$\begin{array}{l}\text { Ficus carica L. } \\
\text { (Moraceae) Anjir }\end{array}$} & $\begin{array}{l}\text { Ripe } \\
\text { fruits }\end{array}$ & Raw; Orally & - & $2-3$ & $\begin{array}{l}\text { In Cancer(02) and } \\
\text { As Antispasmodic (15) }\end{array}$ \\
\hline & & Leaves & Extract; Orally & Twice a day & $\begin{array}{l}\text { Half tea } \\
\text { spoon }\end{array}$ & Tuberculosis*(01) \\
\hline & & \multicolumn{5}{|c|}{$\begin{array}{l}\text { * Smoke of Ficus Bark is inhaled in some ethnic localities but this use was denied if a } \\
\text { patient is suffering from migraine. }\end{array}$} \\
\hline 9. & $\begin{array}{l}\text { Grewia optiva Drumm. } \\
\text { (Malvaceae) Beyul }\end{array}$ & Leaves & Paste; Poultice & -5 & 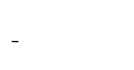 & Joint pains(15) \\
\hline
\end{tabular}




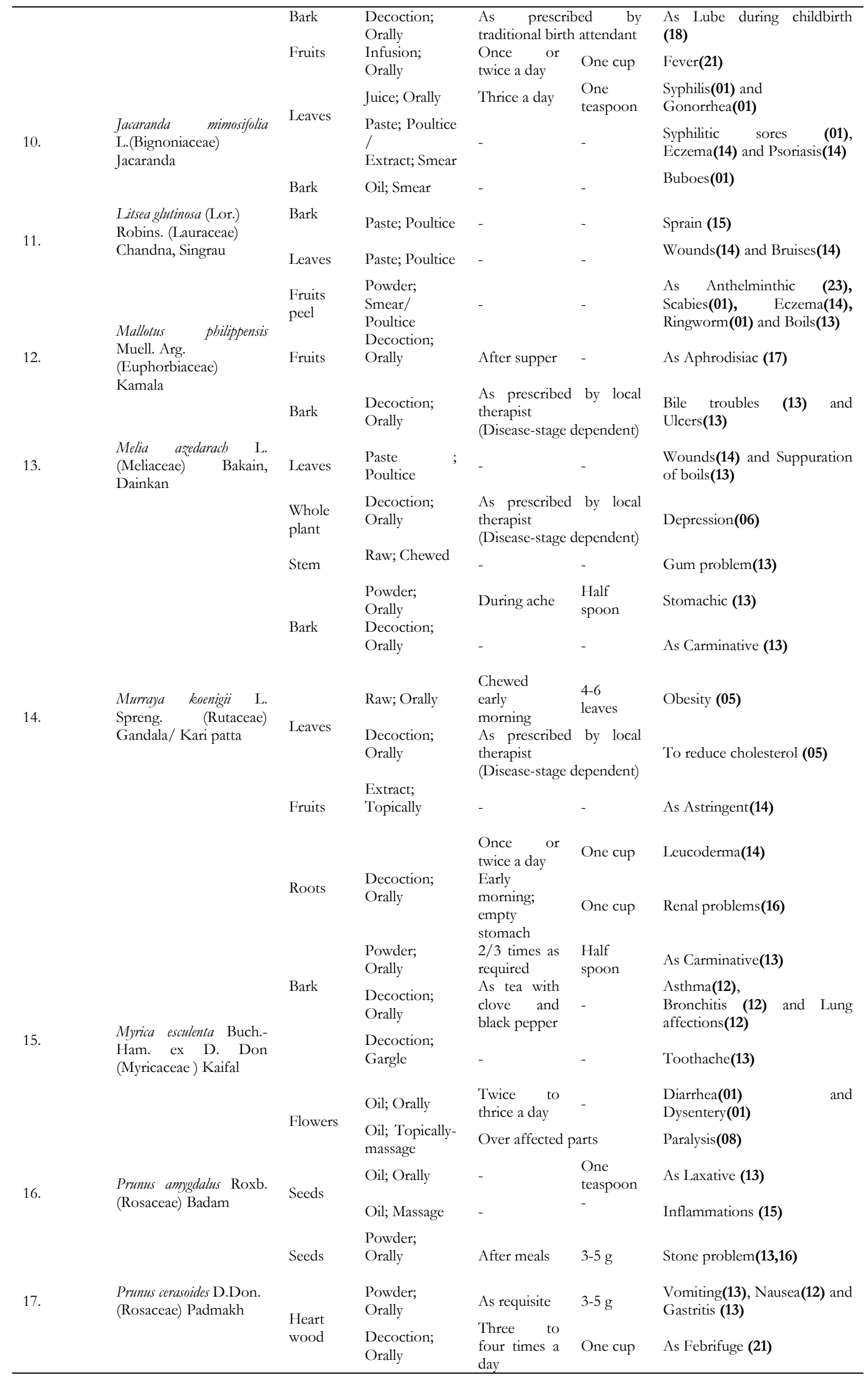




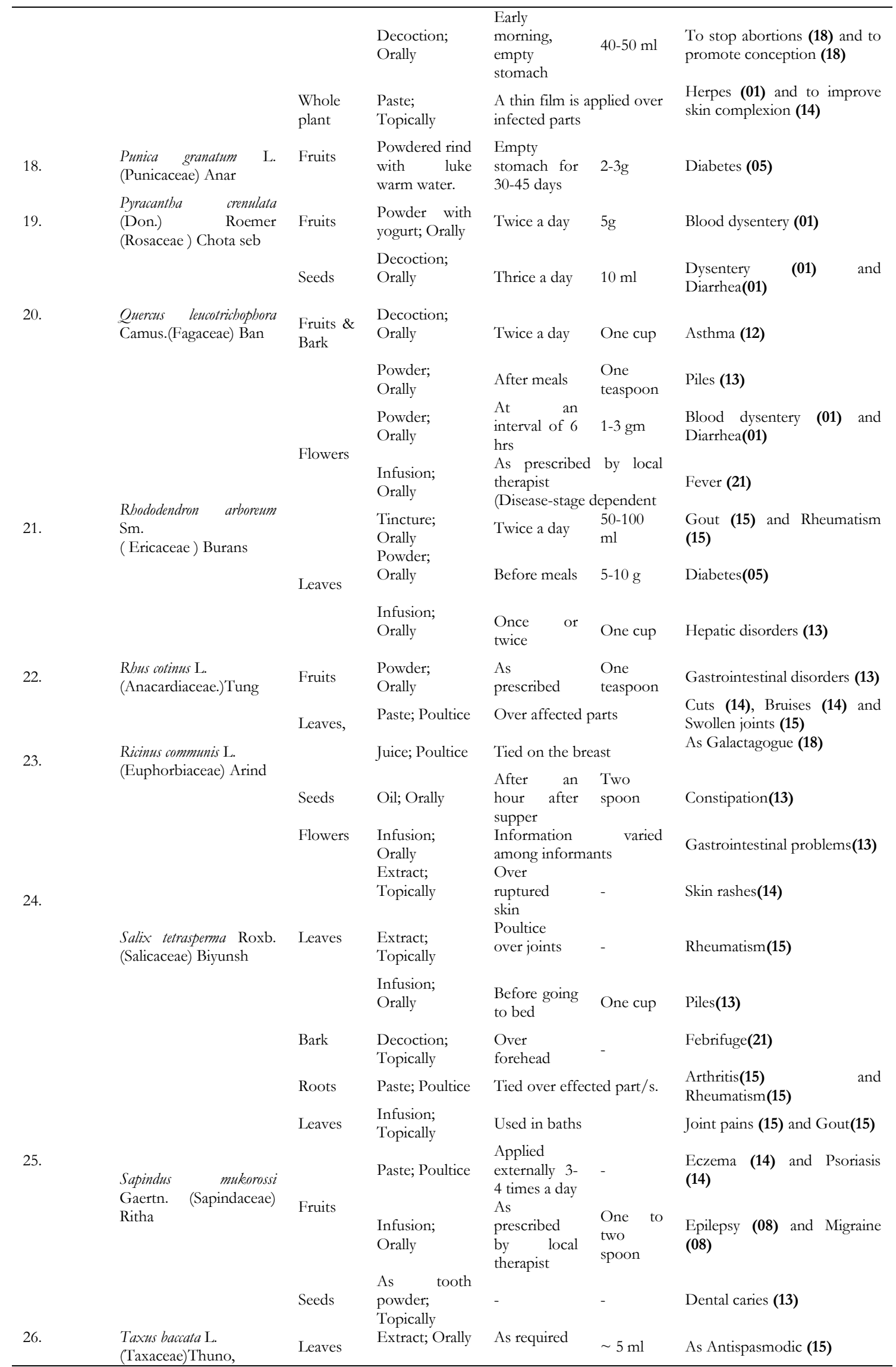




\begin{tabular}{|c|c|c|c|c|c|}
\hline Barmi & \multirow{6}{*}{$\begin{array}{l}\text { Tender } \\
\text { shoots }\end{array}$} & \multirow[b]{2}{*}{$\begin{array}{l}\text { Infusion; } \\
\text { Orally }\end{array}$} & $\begin{array}{l}\text { Extract is } \\
\text { ingested } \\
\text { with } 3-5 \\
\text { drops of } \\
\text { almond oil }\end{array}$ & $\begin{array}{l}\text { One } \\
\text { teaspoon }\end{array}$ & $\begin{array}{l}\text { Nervousness(08), } \\
\text { Hysteria(07) and } \\
\text { Epilepsy(08) }\end{array}$ \\
\hline & & & $\begin{array}{l}\text { Twice a day, } \\
\text { before meals }\end{array}$ & One cup & Stone problem $(13,16)$ \\
\hline & & $\begin{array}{l}\text { Tincture; } \\
\text { Orally }\end{array}$ & - & $\sim 5 \mathrm{ml}$ & $\begin{array}{lll}\text { Headache } & (\mathbf{0 8}) \quad \text { and } \\
\text { Giddiness(21) }\end{array}$ \\
\hline & & Extract; Orally & - & $3-5$ drops & Feeble and falling pulse (21) \\
\hline & & $\begin{array}{l}\text { Infusion; } \\
\text { Orally }\end{array}$ & - & One cup & $\begin{array}{l}\text { Diarrhea }(\mathbf{0 1}) \\
\text { Biliousness(13) }\end{array}$ \\
\hline & & $\begin{array}{l}\text { Powder; } \\
\text { Orally }\end{array}$ & $\begin{array}{l}\text { Twice a day } \\
\text { with onset } \\
\text { of tumor }\end{array}$ & $\begin{array}{l}\text { One } \\
\text { teaspoon }\end{array}$ & Tumor(02) and Cancer(02) \\
\hline & Roots & Paste; Poultice & $\begin{array}{l}\text { Root paste in } \\
\text { smeared over } \\
\text { parts }\end{array}$ & $\begin{array}{r}\text { olive oil is } \\
\text { affected }\end{array}$ & Leprosy(01) \\
\hline \multicolumn{6}{|l|}{ Disease category (DC): } \\
\hline 01.Certain infectious or parasitic disease & & \multicolumn{3}{|c|}{ 13.Diseases of the digestive system } & \\
\hline 02.Neoplasms & & \multicolumn{3}{|c|}{ 14.Diseases of the skin } & \\
\hline 03.Diseases of the blood / blood-formir & organs & \multicolumn{4}{|c|}{ 15.Diseases of the musculoskeletal system or connective tissue } \\
\hline 04.Diseases of the immune system & & \multicolumn{4}{|c|}{ 16.Diseases of the genitourinary system } \\
\hline 05.Endocrine, nutritional or metabolic c & seases & \multicolumn{3}{|c|}{ 17.Conditions related to sexual healt } & \\
\hline 06.Mental, behavioural / neuro-develop & nental disorder & \multicolumn{4}{|c|}{$\begin{array}{l}\text { 17.Conditions related to sexual health } \\
\text { 18.Pregnancy, childbirth or the puerperium }\end{array}$} \\
\hline 07.Sleep-wake disorders & & \multicolumn{4}{|c|}{ 19.Certain conditions originating in the perinatal period } \\
\hline 08.Diseases of the nervous system & & \multicolumn{3}{|c|}{ 20.Developmental anomalies } & \\
\hline 09.Diseases of the visual system & & \multicolumn{4}{|c|}{ 21.Symptoms, signs or clinical findings, not elsewhere classified } \\
\hline 10.Diseases of the ear or mastoid proce & & \multicolumn{4}{|c|}{ 22.Injury, poisoning or certain other consequences of external causes } \\
\hline 11.Diseases of the circulatory system & & \multicolumn{4}{|c|}{ 23.External causes of morbidity or mortality } \\
\hline 12.Diseases of the respiratory system & & \multicolumn{4}{|c|}{ 24.Factors influencing health status or contact with health services } \\
\hline \multicolumn{6}{|c|}{$\begin{array}{l}\text { ("Three teaspoons" equals "one tablespoon" or generally as "spoon" where one teaspoon equals approximately } 5 \mathrm{ml} \text { or } 4 \mathrm{~g} \text {. Half-glass } \\
\text { equals } 100 \text { or } 120 \mathrm{ml} \text { whereas one cup measures } 80 \text { to } 100 \mathrm{ml} \text { ). No prohibitory food supplements were recorded in any citation. }\end{array}$} \\
\hline
\end{tabular}

\section{Result and Discussion}

Ethno-medicinal survey of various tribal localities of Chamba district with respect to tree species reveals 121 therapeutic usages of 26 trees for 16 body system and 75 disease category/ ailments as included in ICD-11. No therapeutic usage report regarding diseases of the immune system, visual system, ear or mastoid process and blood /bloodforming organs or circulatory system was observed. Among local therapies, doses of drugs are generally measured through household implement or utensils (Cetto and Heinrich, 2011). Indigenous peoples were highly aware about various topical and internal infections and used various anti-microbial/s accordingly as Baubinia variegate and Taxus baccata for leprosy, Cinnamomum tamala and Ficus carica for tuberculosis, Jacaranda mimosifolia and Sapindus mukorossi for psoriasis, Jacaranda mimosifolia, Mallotus philippensis and Sapindus mukorossi for eczema and Prunus cerasoides for herpes. Biomolecules are either cidal or static to micro-organisms as they interfere in their biochemical pathways or hinder the substrate product equilibrium (Lal and Singh, 2008; Jain et al., 2017).

Informants were not aware about the concept of malignancy with respect to cancer and tumor. Therefore, the plant usages in cases where the patient was clinically diagnosed for cancer were included in cancer subcategory while all clinically undiagnosed masses of tissues were included under tumors. Ficus carica and Taxus baccata are used to treat malignant tumors. Plant derived flavanoid/s are effective anti-cancerous molecules and reported plants are the good sources of flavanoid/s group therefore, they are ought to have anti-cancerous properties (Cragg and Newman, 2005).

Among studied communities obesity is considered to be an outcome of over eating and they do not relate it to any other metabolic disorder. Among tree species Baubinia variegate and Murraya koenigii are used to reduce the stuffed body fat. Murraya koenigii is rich in fiber which in turn may help in early satiety, less uptake and weight loss. Symptoms related to sugar anomaly was recorded to differentiate the sub-category of diabetes. Among diabetes mellitus no juvenile or gestational record was obtained and the informants were not aware about diabetes inspidus. Therefore, in present documentation diabetes generally refers to diabetes mellitus II. Punica granatum and Rhododendron arboretum are used to reduce high glycemic levels. The active components of these plants effectively seizes post prandial hyperglycemia (Arora and Paliwal, 2015).

According to local therapist Prunus cerasoides and Taxus baccata are used to get rid of stone problems but they were unable to demarcate between kidney and gall bladder stones. Citrus limon and Rhododendron arboretum are used to treat liver disorders. These plants may affect the transaminase activity and 
thereby effecting SGOT and SGPT levels in hepatocytes. Amidst mental, behavioural / neurodevelopmental disorders the stress and depression sounds aloud. Murraya koenigii is used in either ways to treat depression. Paralysis is a loss of muscle function in part of the body. It can be temporary or permanent. The most common causes are stroke, spinal cord injury and multiple sclerosis. Gaddi tribe specifically uses Myrica esculenta for the treatment of paralysis (Table 1.1).

Chamba (HP) is a region of harsh conditions which forms a colder desert with a pertaining low temperature leading to slow biochemical processes and abundance of parasitic activity, thereby making people more prone to internal and external infections (Lal et al., 1996). In addition roughed hilly areas also affect musculo-endothelial tissues of the higher biotic communities. Therefore, people residing in such harsh conditions are more aware about their remedies (Badola, 2001).

Rheumatism tends to be used as synonym for variety of symptoms such as joint pain and inflammation. Among inflammatory joint diseases rheumatoid arthritis represents the most common form of chronic and systemic inflammatory disease and is marked by synovial hyperplasia with local invasion of bone and cartilage leading to joint destruction (Ahmed et al., 2005). Rhododendron arboretum, Salix tetrasperma and Sapindus mukorossi are used to treat rheumatism and are in accordance to criss-cross tally among different ethnic pouches.

\section{Conclusion}

Maximum citation i.e. 24 use reports were obtained for disease related to digestive system i.e. the indigenous tribal peoples were more versed to the plants that can be deployed to get relief from the disorders and discomforts of digestive tract followed by maladies of skin. Local groups also expertise in therapeutic access to the diseases and affects of parasites on internal (with 21 use reports) and external milieu leading to various skin diseases followed by therapeutic usages for endo-muscular ailments. Among local herdsman least information prevailed for therapeutic uses of tree species for mental, behavioural / neuro-developmental disorders, sleep-wake disorders, conditions related to sexual health and injury, poisoning or certain other consequences of external causes. Among documented tree species Taxus baccata was found to be highest multi-purpose medico species as it is deployed in 13 ailments belonging to 8 disease categories followed by Murraya koenigii, Prunus cerasoides and Sapindus mukorossi which are used in 9 ailments. Among these three species Prunus cerasoides is comparatively more versatile as it is used in six categories of disease followed by Murraya koenigii and Sapindus mukorossi. Albizia lebbeck, Celtis australis,
Citrus limon, Eucalyptus bybridium, Punica granatum, Pyracantha crenulata and Rhus cotinus are used in solo pan i.e. they are used for single maladies. It can be also be inferred that they are more specific in their mode of action contrary to versatile multi-purpose Taxus baccata.

\section{References}

1. Ahmed S, Anuntiyo J, Malemud CJ and Haqqi TM, Biological basis for the use of botanicals in osteoarthritis and rheumatoid arthritis: a Review, Evidence-Based Complementary and Alternative Medicine, 2005, 2(3), 301-08.

2. Andrade Cetto A and Heinrich M, From the field into the lab: Useful approaches to selecting species based on local knowledge, Front. in Pharmacology, 2011,2,20-23.

3. Arora A and Paliwal V, An Inventory of Traditional Herbal Medicines Used in Management of Diabetes Mellitus II by Ethnic People of South-East Rajasthan (India), Int. J. Pharm. Sci. Rev. Res., 2015, 30(1), 200-04.

4. Badola HK, Medicinal plant diversity in Himachal Pradesh, 407-430. In: Samant, S.S., Dhar, U. and Palani, L.M.S. (eds.) Himalayan Medicinal Plants: Potential and Prospects. Gyanodya Prakashan. Kanpur (India), 2001.

5. Chauhan NS, Important medicinal and aromatic plants of Himachal Pradesh, Indian Forester, 2003, 129(8), 979-98.

6. Cragg GM and Newman DJ, Plants as a source of anti-cancer agents, Journal of Ethnopharmacology, 2005, 100(1), 72-79.

7. Dutt B, Nath D, Chauhan NS, Sharma KR and Sharma SS, Ethno-medicinal Plant Resources of Tribal Pangi Valley in District Chamba, Himachal Pradesh, India, Inter. J. of Bio-resource and Stress Management, 2014, 5(3), 416-21.

8. Guleria V and Vasishth A, Ethnobotanical Uses of Wild Medicinal Plants by Gaddi and Gujjar Tribes of Himachal Pradesh, Ethnobotanical Leaflets, 2009, 13: 1158-67.

9. Gupta R, Survey record of medicinal and aromatic plants of Chamba Forest Division of H.P. Indian Forester, 1964, 90, 454-68.

10. Gupta R, Medicinal and aromatic plants of Bhandal ranges, Churah forest division, Chamba district, Himachal Pradesh, J. Bomb. Nat. His. Soc., 1971, 68, 791-803.

11. Jain VC, Akbari BV, Sonara G, Viradiya K and Bhenjaliya $H$, Design and Development of polyherbal lotion for skin repigmentation therapies in Vitiligo, Pharma. Science Monitor, 2017, 8(1), 32-34.

12. Lal B and Singh KN, Indigenous herbal remedies used to cure skin disorders by the natives of LahaulSpiti in H.P, Ind. J. of Trad. Knowl., 2008, 7(2), 237-41. 
13. Lal B, Vats SK., Singh RD and Gupta AK, Plants used as ethnomedicine and supplement food by the Gaddis of Himachal Pradesh, India, in : Jain S.K. (ed) Ethnobiology in Human Welfare, New Delhi,1996.

14. Rani S, Rana JC and Rana PK, Ethnomedicinal plants of Chamba district, Himachal Pradesh, Journal of Med. Plants Res.,2013, 7(42), 3147-57.

15. Shabnam SR, Medicinal Plants of Chamba, Indian Forester, 1964, 90, 50-63.

16. Singh AP and Minoo P, The floral diversity of Gujarat State: a Review, Indian Forester, 2003, 129(12), 1461-69.

17. Singh $\mathrm{H}$ and Sharma M, Flora of Chamba District (Himachal Pradesh). Bishen Singh Mahendra Pal Singh Publications, Dehradun, 2006.

18. Thakur DN, Studies on diversity of medicinal and aromatic plants of Pangi valley in Chamba District,
Himachal Pradesh. M.Sc. thesis, Dr. Y. S. Parmar University of Horticulture and Forestry, Nauni, Solan (HP), India, 2007.

19. Thakur M, Asrani RK, Thakur S Sharma PK, Patil RD, Lal B and Prakash O, Observations on traditional usage of ethnomedicinal plants in humans and animals of Kangra and Chamba districts of Himachal Pradesh in North-Western Himalaya, India, Journal of Ethnopharmacology.2016,191, 280-300.

\section{WHO.2017}

http://www.who.int/classifications/icd/revision/en / and https://icd.who.int/dev11/1-m/en

\section{Cite this article as:}

Asha Arora, Mukesh Sharma and Sushma Gupta. Ethnomedicinal studies of some tree species of Chamba district (Himachal Pradesh) India. Annals of Plant Sciences 7.2 (2018) pp. 2056-2062.

do $\mathrm{http}: / /$ dx.doi.org/10.21746/aps.2018.7.2.12

Source of support: Director, Botanical Survey of India

Conflict of interest: Nil 